\title{
Endophytic bacterial diversity in banana 'Prata Anã' (Musa spp.) roots
}

\author{
Suzane A. Souza ${ }^{1}$, Adelica A. Xavier ${ }^{2}$, Márcia R. Costa ${ }^{2}$, Acleide M.S. Cardoso ${ }^{2}$, \\ Marlon C.T. Pereira ${ }^{2}$ and Silvia Nietsche ${ }^{2}$ \\ ${ }^{1}$ Laboratório de Biotecnologia, Centro de Biociências e Biotecnologia, \\ Universidade Estadual do Norte Fluminense Darcy Ribeiro, Campo dos Goytacazes, RJ, Brazil. \\ ${ }^{2}$ Laboratório de Biotecnologia, Departamento de Ciências Agrárias, \\ Universidade Estadual de Montes Claros, Janaúba, MG, Brazil.
}

\begin{abstract}
The genetic diversity of endophytic bacteria in banana 'Prata Anã' roots was characterized. Two hundred and one endophytic bacteria were isolated, 151 of which were classified as Gram-positive and 50 as Gram-negative. No hypersensitivity response was observed in any of the isolates. The rep-PCR technique generated different molecular profiles for each primer set (REP, ERIC and BOX). Fifty readable loci were obtained and all of the fragments were polymorphic. Amplified ribosomal DNA restriction analysis (ARDRA) of the isolates based on cleavage with four restriction enzymes yielded 45 polymorphic bands and no monomorphic bands. PCR amplified the nifH gene in 24 isolates. $16 \mathrm{~S}$ rDNA sequencing of the 201 bacterial isolates yielded 102 high-quality sequences. Sequence analyses revealed that the isolates were distributed among ten bacterial genera (Agrobacterium, Aneurinibacillus, Bacillus, Enterobacter, Klebsiella, Lysinibacillus, Micrococcus, Paenibacillus, Rhizobium and Sporolactobacillus) and included 15 species. The greatest number of isolates belonged to the genus Bacillus. The bacteria identified in this study may be involved in promoting growth, phosphate solubilization, biological control and nitrogen fixation in bananas.
\end{abstract}

Keywords: ARDRA, Bacillus sp., nifH gene, rep-PCR, 16S rDNA.

Received: August 7, 2012; Accepted: February 27, 2013.

\section{Introduction}

Bananas are important agricultural products in most tropical countries, with the world production estimated to be 90.7 million tons. Brazil is ranked fourth among banana producers, with a production of 7,116,808 tons and a harvested area of 510,825,000 hectares (FAO, 2010). Plants, including banana trees, are complex micro-ecosystems in which different niches are filled by a wide variety of microorganisms, including endophytes (Mia et al., 2010). In recent years, there has been considerable interest in the study of endophytic microorganisms and the determination of their role in plants. Endosymbionts act as biological control agents in numerous diseases (Jie et al., 2009), in the promotion of plant growth (Ryan et al., 2008) and in the bioremediation of polluted areas (Germaine et al., 2009). The use of these microorganisms is preferred compared to chemical fertilizers and pesticides because of their lower cost and their contribution to sustainable agriculture (Aung et al., 2011).

Send correspondence to Silvia Nietsche. Laboratório de Biotecnologia, Departamento de Ciências Agrárias, Universidade Estadual de Montes Claros, Campus de Janaúba, Avenida Reinaldo Viana 2630, Caixa Postal 91, 39440-000 Janaúba, MG, Brazil. E-mail: silvia.nietsche@unimontes.br.
Various molecular techniques have been used to characterize endophytic bacteria, including repetitive extragenic palindromic sequence PCR (rep-PCR), which uses the conserved sequences of ERIC, REP and BOX, 16S rDNA amplification and restriction, and the cloning and sequencing of the amplified genes (Ryan et al., 2008). Additionally, primers specific for the amplification of important bacterial genes, such as nifH (necessary for nitrogen fixation), or genes involved in the degradation of organic pollutants, have been used to study the potential participation of endophytic bacteria in important processes of the host plant (Ryan et al., 2008).

For more than 60 years, bacteria have been known to co-exist with plants without causing any damage. The first reports of endophytic bacteria in banana trees were published in the 1990s and increased from 2000 onwards. However, few advances have been made in isolating and characterizing these endophytic bacteria and in understanding their diversity and functions in bananas. Some genera have been described as banana colonizers, including Azospirillum amazonense, Azospirillum brasilense, Bacillus, Burkholderia cepacia, Burkholderia spp., Citrobacter sp., Enterobacter spp., Klebsiella spp., Klebsiella variicola, Ochrobactrum, Pantoea, Serratia and Staphylo- 
coccus epidermidis (Rosenblueth et al., 2004; Thomas et al., 2008; Ting et al., 2008; Jie et al., 2009).

The objective of this study was to isolate and identify banana endophytic bacteria and to assess their genetic diversity based on rep-PCR, ARDRA and partial $16 \mathrm{~S}$ rDNA sequencing.

\section{Material and Methods}

\section{Plant sampling and bacterial isolation}

Roots from juvenile 'Prata Anã' plants were collected in four counties in Minas Gerais State and in one county in Bahia State, Brazil. The banana root fragments were immersed in $70 \%$ ethanol for $1 \mathrm{~min}$ and $4 \%$ sodium hypochlorite $(\mathrm{NaClO})$ for $3 \mathrm{~min}$ and then washed three times in sterile, distilled water. The fragments were subsequently exposed to ultraviolet light in a flow chamber for $10 \mathrm{~min}$ and subjected to an ultrasound bath for $10 \mathrm{~min}$. After two baths, the fragments were macerated and the suspensions were diluted 10 fold. A $0.1 \mathrm{~mL}$ aliquot was plated onto each of the following media: nutrient yeast dextrose agar (NYDA; $10 \mathrm{~g}$ dextrose, $5 \mathrm{~g}$ yeast extract, $3 \mathrm{~g}$ beef extract, $5 \mathrm{~g}$ peptone and $18 \mathrm{~g}$ agar), potato dextrose agar (PDA; $200 \mathrm{~g}$ potato starch, $20 \mathrm{~g}$ dextrose and $20 \mathrm{~g}$ agar) and tryptic soy agar ( $30 \mathrm{~g}$ TSA). The plates were incubated for $48 \mathrm{~h}$ at $25 \pm 1{ }^{\circ} \mathrm{C}$ on a $12 \mathrm{~h}$ photoperiod. The different media described above were used for bacterial isolation and further culturing.

The bacterial isolates were characterized by Gram staining and, to assess pathogenicity, the isolates were inoculated into non-host plants, including pepper (Capsicum annuum Mill), tobacco (Nicotiana tabacum L.) and common bean (Phaseolus vulgaris L.) seedlings grown in a greenhouse. The infected plants were monitored for hypersensitivity responses as described by Romeiro (2001).

\section{Total DNA extraction and 16S rDNA sequencing}

For DNA extraction, each isolate was grown in liquid tryptic soy broth (TSB) for $24 \mathrm{~h}$ at $37^{\circ} \mathrm{C}$ under constant mixing at $180 \mathrm{rpm}$. Bacterial genomic DNA was extracted with a DNA extraction kit (Qiagen, Valencia, CA, USA), according to the manufacturer's recommendations.

The isolates were identified by partial sequencing of the $16 \mathrm{~S}$ region. Initially, the $16 \mathrm{~S}$ region was amplified using primers $27\left(5^{\prime}\right.$-AGAGTTTGATC(AC)TGGCTCAG$\left.-3^{\prime}\right)$ and 1492R (5'-ACGG(CT)TACCTTGTTACGAC TT-3'). The reactions consisted of $2 \mu \mathrm{L}$ of dNTPs $(2.0 \mathrm{mM}$ each), $2.5 \mu \mathrm{L}$ of $10 \mathrm{X}$ buffer, $0.75 \mu \mathrm{L}$ of $50 \mathrm{mM} \mathrm{MgCl}_{2}$, $2.5 \mu \mathrm{L}$ of each primer $(5 \mathrm{mM}), 0.3 \mu \mathrm{L}$ of Taq polymerase (5 U/ $\mu \mathrm{L}), 50 \mathrm{ng}$ of template DNA and sterile Milli-Q water in a final volume of $25 \mu \mathrm{L}$. The amplification conditions consisted of an initial denaturation at $94{ }^{\circ} \mathrm{C}$ for $3 \mathrm{~min}$, followed by 30 cycles of $94{ }^{\circ} \mathrm{C}$ for $30 \mathrm{~s}, 50{ }^{\circ} \mathrm{C}$ for $30 \mathrm{~s}$ and $72{ }^{\circ} \mathrm{C}$ for $1 \mathrm{~min}$ and a final extension at $72{ }^{\circ} \mathrm{C}$ for $7 \mathrm{~min}$.
DNA was purified using a QIAquick gel extraction kit (Qiagen). Sample sequencing was done using an automated sequencer (ABI-PRISM 3100 Genetic Analyzer). The resulting sequences were compared with those present in the National Center for Biotechnology Information (NCBI) database (www.ncbi.nlm.nih.gov) by using the basic local alignment search tool (BLAST) software for nucleotides (Altschul et al., 1997). The bacterial isolates were identified to the species level when similarity values varied between $98 \%$ and $100 \%$ and to the genus level when similarity values were $<98 \%$.

\section{Nucleotide sequence accession numbers}

The nucleotide sequence data reported in this paper have been deposited in the GenBank nucleotide sequence database under accession numbers JQ979307-JQ979408.

\section{REP-PCR amplification}

The isolates were compared using the genomic profiles obtained by rep-PCR (repetitive-PCR). The following primers were used: REP1R-I (5'-IIIICGICGICATCI GGC-3'), REP2-I (5'-ICGITTATCIGGCCTAC-3'), ERIC1R (5'-ATGTAAGCTCCTGGGGATTCA-3'), ERIC2 (5'-AAGTAAGTGACTGGGGTGAGCG-3') and BOX 1AR (5'-CTCCGGCAAGGCGACGCTGAC-3') (Louws et al., 1994). Each reaction contained $2.5 \mu \mathrm{L}$ of 10X buffer, $0.7 \mu \mathrm{L}$ of $50 \mathrm{mM} \mathrm{MgCl} 2,2 \mu \mathrm{L}$ of dNTPs (2.5 mM each), $1 \mu \mathrm{L}$ of each primer $(5 \mu \mathrm{M}), 0.3 \mu \mathrm{L}$ of Taq polymerase $(5 \mathrm{U} / \mu \mathrm{L}), 3 \mu \mathrm{L}$ of DNA $(10 \mathrm{ng} / \mu \mathrm{L})$ and sterile ultrapure (Milli-Q-treated) water in a total volume of $25 \mu \mathrm{L}$. The amplification conditions consisted of an initial denaturation at $95^{\circ} \mathrm{C}$ for $7 \mathrm{~min}$, followed by 30 cycles of $94{ }^{\circ} \mathrm{C}$ for $1 \mathrm{~min}$, primer annealing for $1 \mathrm{~min}\left(53^{\circ} \mathrm{C}\right.$ for the BOX $1 \mathrm{AR}$ primer, $39^{\circ} \mathrm{C}$ for the REP primer and $52^{\circ} \mathrm{C}$ for ERIC), extension at $65^{\circ} \mathrm{C}$ for $8 \mathrm{~min}$ and a final extension step $\left(65^{\circ} \mathrm{C}\right.$ for $\left.15 \mathrm{~min}\right)$. The PCR products were run on $1.5 \%$ agarose gels stained with ethidium bromide. The size of the amplified fragments was estimated with a 100-bp molecular weight DNA ladder.

\section{ARDRA amplification}

Endophytic bacterial DNA was amplified with the following primers: FGPS1490 5'-TGCGGCTGGATCAC CTCCTT-3' and FGPS132 5'-CCGGGTTTCCCCATTC GG-3'. The amplification reactions contained $0.8 \mu \mathrm{L}$ of dNTPs ( $2.0 \mathrm{mM}$ each), $2.5 \mu \mathrm{L}$ of $10 \mathrm{X}$ buffer, $0.75 \mu \mathrm{L}$ of $50 \mathrm{mM} \mathrm{MgCl}_{2}, 0.25 \mu \mathrm{L}$ of each primer $(5 \mathrm{mM}), 0.2 \mu \mathrm{L}$ of Taq polymerase $(5 \mathrm{U} / \mu \mathrm{L})$ and $50 \mathrm{ng}$ of DNA in a final volume of $25 \mu \mathrm{L}$. The amplification conditions consisted of an initial denaturation step $\left(95^{\circ} \mathrm{C}\right.$ for $\left.3 \mathrm{~min}\right)$ followed by 35 cycles of $94^{\circ} \mathrm{C}$ for $1 \mathrm{~min}, 60^{\circ} \mathrm{C}$ for $1 \mathrm{~min}$ and $72^{\circ} \mathrm{C}$ for $2 \mathrm{~min}$, with a final extension at $72{ }^{\circ} \mathrm{C}$ for $3 \mathrm{~min}$.

The amplification products were digested with the restriction enzymes Hinfl, MspI, NdeI and RsaI. Each enzy- 
matic reaction contained $10 \mu \mathrm{L}$ of PCR product, $2 \mu \mathrm{L}$ of $10 \mathrm{X}$ enzyme-specific buffer, $2 \mu \mathrm{L}$ of enzyme (5 U/reaction) and $18 \mu \mathrm{L}$ of sterile Milli-Q water. The reactions were incubated for $16 \mathrm{~h}$ in a water bath at $37^{\circ} \mathrm{C}$. The fragments were analyzed by electrophoresis on $1.2 \%$ agarose gels in $1 \mathrm{X}$ $\mathrm{TBE}$ at $100 \mathrm{~V}$ for $3 \mathrm{~h}$. The size of the amplified fragments was estimated with a 100-bp molecular weight DNA ladder.

\section{nifH gene PCR amplification}

DNA from root isolates was analyzed for the presence of the nifH gene using the universal primers $19 \mathrm{f} F$ (5'-GGAATTCTGTGACCTAAAGCTGA-3') and $407 \mathrm{R}$ (5'-AGCATACATTGCCATCATTTCACC-3'). The amplification reaction mixtures contained $2.0 \mu \mathrm{L}$ of dNTPs (2.0 mM each), $2.5 \mu \mathrm{L}$ of $10 \mathrm{X}$ buffer, $1 \mu \mathrm{L}$ of $50 \mathrm{mM}$ $\mathrm{MgCl}_{2}, 0.5 \mu \mathrm{L}$ of each primer $(5 \mathrm{mM}), 0.6 \mu \mathrm{L}$ of Taq polymerase $(5 \mathrm{U} / \mu \mathrm{L})$ and $50 \mathrm{ng}$ of DNA in a final volume of $25 \mu \mathrm{L}$. The amplification conditions consisted of denaturation at $94^{\circ} \mathrm{C}$ for $2 \mathrm{~min}$, followed by 30 cycles of $94^{\circ} \mathrm{C}$ for $30 \mathrm{~s}, 52^{\circ} \mathrm{C}$ for $30 \mathrm{~s}$ and $72{ }^{\circ} \mathrm{C}$ for $30 \mathrm{~s}$, with a final extension at $72{ }^{\circ} \mathrm{C}$ for $7 \mathrm{~min}$. The amplification products were analyzed by electrophoresis on $1.2 \%$ agarose gels and fragments of $\sim 270$ bp were expected for the nifH gene. The size of the amplified fragments was estimated with a 100-bp molecular weight DNA ladder.

\section{Statistical analyses}

The ARDRA and rep-PCR results were analyzed cumulatively with R 2.13 software based on the coefficient of simple matching. Cluster analysis was done by the unweighted pair group method with arithmetic mean (UPGMA) using MEGA 5 software (Tamura et al., 2011).

\section{Results}

\section{Bacterial isolation and $16 \mathrm{~S}$ rDNA sequencing}

201 isolates of endophytic bacteria were obtained from the roots of 'Prata Anã' banana plants; 150 of these isolates were classified as Gram-positive and 51 as Gramnegative. There was no hypersensitivity response in tobacco (N. tabacum L.), bell pepper (C. annuum Mill) and common beans $(P$. vulgaris L.) five days after inoculation of the bacterial isolates.

Partial sequencing of the 16S rDNA from the 201 bacterial isolates yielded 102 high-quality sequences. Analysis of these sequences revealed that the isolates were from 15 species belonging to ten genera: Agrobacterium, Aneurinibacillus, Bacillus, Enterobacter, Klebsiella, Lysinibacillus, Micrococcus, Paenibacillus, Rhizobium and Sporolactobacillus (Table 1).

The genus Bacillus was identified most frequently (87.3\% of isolates), followed by the genus Lysinibacillus

Table 1 - Distribution of partially identified 16S rDNA sequences detected in endophytic isolates from 'Prata Anã' banana tree roots.

\begin{tabular}{|c|c|c|c|c|c|c|}
\hline Isolates & E-value $^{1}$ & Identity $^{2}$ & Most closely related organism ${ }^{3}$ & Gram test & nifH gene & GenBank accession no. ${ }^{4}$ \\
\hline EB-01 & 0.0 & $98 \%$ & Bacillus pumilus & + & - & HM006706.1 \\
\hline EB-04 & 0.0 & $98 \%$ & Bacillus subtilis & + & + & AY741264.1 \\
\hline EB-05 & $7 . \mathrm{e}^{-119}$ & $99 \%$ & Bacillus pumilus & + & - & HQ218993.1 \\
\hline EB-07 & 0.0 & $98 \%$ & Agrobacterium tumefaciens & - & - & GU784794.1 \\
\hline EB-09 & $1 . \mathrm{e}^{-116}$ & $98 \%$ & Bacillus subtilis & + & - & AY741264.1 \\
\hline EB-10 & $1 . \mathrm{e}^{-136}$ & $98 \%$ & Bacillus pumilus & + & - & GQ917222.1 \\
\hline EB-11 & $5 . e^{-172}$ & $97 \%$ & Bacillus sp. & + & - & HQ218993.1 \\
\hline EB-12 & $4 . \mathrm{e}^{-116}$ & $98 \%$ & Bacillus pumilus & + & - & GQ917222.1 \\
\hline EB-14 & 0.0 & $99 \%$ & Bacillus pumilus & + & - & HQ218993.1 \\
\hline EB-15 & $4 . \mathrm{e}^{-127}$ & $98 \%$ & Bacillus pumilus & + & - & GQ917222.1 \\
\hline EB-16 & $4 . \mathrm{e}^{-111}$ & $97 \%$ & Bacillus sp. & + & - & AJ550463.1 \\
\hline EB-17 & $2 . \mathrm{e}^{-109}$ & $97 \%$ & Bacillus sp. & + & - & JF802184.1 \\
\hline EB-23 & $3 . e^{-179}$ & $98 \%$ & Klebsiella pneumoniae & - & + & JN201948.1 \\
\hline EB-24 & 0.0 & $98 \%$ & Bacillus thuringiensis & + & + & JF947357.1 \\
\hline EB-25 & 0.0 & $98 \%$ & Bacillus cereus & + & + & GU451184.1 \\
\hline EB-26 & 0.0 & $98 \%$ & Bacillus methylotrophicus & + & - & HM209756.1 \\
\hline EB-27 & 0.0 & $97 \%$ & Bacillus sp. & + & - & HQ256520.1 \\
\hline EB-28 & $1 . \mathrm{e}^{-163}$ & $96 \%$ & Paenibacillus sp. & + & + & EF178460.1 \\
\hline EB-30 & 0.0 & $98 \%$ & Bacillus axarquienses & + & - & JF414764.1 \\
\hline EB-34 & $1 . \mathrm{e}^{-131}$ & $98 \%$ & Bacillus pumilus & + & - & $\mathrm{JN} 215511.1$ \\
\hline EB-35 & $2 . \mathrm{e}^{-88}$ & $94 \%$ & Bacillus sp. & + & - & GQ340516.1 \\
\hline
\end{tabular}


Table 1 (cont.)

\begin{tabular}{|c|c|c|c|c|c|c|}
\hline Isolates & E-value ${ }^{1}$ & Identity $^{2}$ & Most closely related organism ${ }^{3}$ & Gram test & nifH gene & GenBank accession no. ${ }^{4}$ \\
\hline EB-37 & $2 . \mathrm{e}^{-146}$ & $96 \%$ & Bacillus sp. & + & - & JN215502.1 \\
\hline EB-38 & $3 . e^{-97}$ & $96 \%$ & Bacillus sp. & - & + & EU931559.1 \\
\hline EB-40 & $7 . e^{-99}$ & $97 \%$ & Bacillus sp. & + & + & GQ340516.1 \\
\hline EB-42 & $2 . \mathrm{e}^{-89}$ & $96 \%$ & Bacillus sp. & + & - & JN082266.1 \\
\hline EB-44 & $4 . e^{-173}$ & $98 \%$ & Bacillus amyloliquefaciens & + & - & GU122948.1 \\
\hline EB-45 & 0.0 & $98 \%$ & Lysinibacillus sp. & + & + & JN215512.1 \\
\hline EB-46 & 0.0 & $99 \%$ & Bacillus pumilus & + & - & FJ236809.1 \\
\hline EB-47 & $1 . e^{-147}$ & $97 \%$ & Bacillus sp. & + & + & FJ611939.1 \\
\hline EB-48 & 0.0 & $98 \%$ & Bacillus subtilis & + & - & AY741264.1 \\
\hline EB-49 & 0.0 & $98 \%$ & Bacillus licheniformis & + & + & EU366371.1 \\
\hline EB-50 & $3 . e^{-108}$ & $96 \%$ & Bacillus sp. & + & + & HM769816.1 \\
\hline EB-51 & 0.0 & $98 \%$ & Bacillus pumilus & + & + & HQ218993.1 \\
\hline EB-52 & $3 . e^{-133}$ & $96 \%$ & Bacillus sp. & + & - & JF313264.1 \\
\hline EB-53 & $7 . e^{-85}$ & $92 \%$ & Lysinibacillussp. & + & - & JN215512.1 \\
\hline EB-55 & $3 . e^{-108}$ & $98 \%$ & Bacillus subtilis & + & - & HQ334981.1 \\
\hline EB-56 & $2 . \mathrm{e}^{-89}$ & $92 \%$ & Bacillus sp. & + & + & GU269573.1 \\
\hline EB-57 & $3 . e^{-102}$ & $96 \%$ & Bacillus safensis & + & - & JN092810.1 \\
\hline EB-58 & $9 . \mathrm{e}^{-139}$ & $98 \%$ & Bacillus pumilus & + & - & JN082265.1 \\
\hline EB-60 & $1 . e^{-112}$ & $96 \%$ & Lysinibacillussp. & + & - & JF906500.1 \\
\hline EB-62 & $5 . \mathrm{e}^{-105}$ & $97 \%$ & Bacillus sp. & + & - & HQ334981.1 \\
\hline EB-63 & $3 . e^{-108}$ & $98 \%$ & Bacillus pumilus & + & - & GQ917222.1 \\
\hline EB-64 & 0.0 & $98 \%$ & Bacillus pumilus & + & + & JF271873.1 \\
\hline EB-65 & 7. $\mathrm{e}^{-171}$ & $97 \%$ & Bacillus sp. & + & - & EU366378.1 \\
\hline EB-68 & $2 . e^{-136}$ & $98 \%$ & Bacillus safensis & + & - & JN092818.1 \\
\hline EB-69 & $6 . e^{-95}$ & $97 \%$ & Bacillus sp. & + & - & GQ34O516.1 \\
\hline EB-70 & $5 . \mathrm{e}^{-167}$ & $96 \%$ & Bacillus sp. & + & - & GQ340516.1 \\
\hline EB-71 & $2 . e^{-166}$ & $97 \%$ & Bacillus sp. & + & + & HM461161.1 \\
\hline EB-73 & $4 . e^{-117}$ & $99 \%$ & Bacillus pumilus & + & - & GQ917222.1 \\
\hline EB-76 & 7. $\mathrm{e}^{-130}$ & $97 \%$ & Bacillus sp. & + & - & FJ937920.1 \\
\hline EB-84 & 0.0 & $98 \%$ & Bacillus subtilis & + & - & HQ334981.1 \\
\hline EB-87 & $8 . e^{-155}$ & $98 \%$ & Bacillus tequilensis & + & + & HM770882.1 \\
\hline EB-88 & $3 . e^{-175}$ & $98 \%$ & Bacillus flexus & + & + & DQ870687.1 \\
\hline EB-89 & $2 . e^{-177}$ & $98 \%$ & Bacillus subtilis & + & - & HQ234331.1 \\
\hline EB-91 & $6 . e^{-100}$ & $97 \%$ & Bacillus sp. & + & - & JN092818.1 \\
\hline EB-98 & $6 . e^{-125}$ & $98 \%$ & Micrococcus luteus & + & - & FJ380958.1 \\
\hline EB-99 & $2 . e^{-136}$ & $96 \%$ & Bacillus sp. & + & - & AB301022.1 \\
\hline EB-101 & $2 . \mathrm{e}^{-95}$ & $98 \%$ & Bacillus pumilus & + & - & JN082266.1 \\
\hline EB-107 & 0.0 & $99 \%$ & Bacillus thuringiensis & + & - & AM292316.1 \\
\hline EB-108 & $2 . \mathrm{e}^{-84}$ & $95 \%$ & Rhizobium sp. & - & - & AY693664.1 \\
\hline EB-111 & $8 . e^{-114}$ & $99 \%$ & Bacillus megaterium & + & - & AM237398.1 \\
\hline EB-113 & $9 . \mathrm{e}^{-120}$ & $92 \%$ & Bacillus sp. & + & - & JN208198.1 \\
\hline EB-117 & 4. $e^{-91}$ & $97 \%$ & Bacillus sp. & + & - & JN082257.1 \\
\hline EB-120 & $6 . \mathrm{e}^{-131}$ & $97 \%$ & Bacillus sp. & + & - & AM921636.1 \\
\hline EB-124 & $1 . e^{-55}$ & $93 \%$ & Bacillus sp. & + & - & EU977719.1 \\
\hline EB-125 & $4 . e^{-137}$ & $98 \%$ & Bacillus pumilus & + & - & HQ858063.1 \\
\hline EB-126 & 0.0 & $98 \%$ & Bacillus subtilis & + & + & HМ769817.1 \\
\hline EB-127 & $2 . \mathrm{e}^{-89}$ & $97 \%$ & Sporolactobacillus sp. & + & + & D16282.1 \\
\hline
\end{tabular}


Table 1 (cont.)

\begin{tabular}{|c|c|c|c|c|c|c|}
\hline Isolates & E-value $^{1}$ & Identity $^{2}$ & Most closely related organism ${ }^{3}$ & Gram test & nifH gene & GenBank accession no. ${ }^{4}$ \\
\hline EB-128 & 0.0 & $99 \%$ & Bacillus pumilus & + & - & EU379285.1 \\
\hline EB-129 & $1 . \mathrm{e}^{-137}$ & $95 \%$ & Bacillus sp. & + & - & HM461228.1 \\
\hline EB-132 & $3 . \mathrm{e}^{-149}$ & $98 \%$ & Bacillus subtilis & + & - & AY741264.1 \\
\hline EB-133 & $1 . \mathrm{e}^{-171}$ & $98 \%$ & Bacillus amyloliquefaciens & + & + & $\mathrm{AB} 301022.1$ \\
\hline EB-134 & $6 . e^{-74}$ & $98 \%$ & Bacillus amyloliquefaciens & + & - & $\mathrm{AB} 301022.1$ \\
\hline EB-135 & $2 . e^{-104}$ & $98 \%$ & Bacillus pumilus & + & - & EU977790.1 \\
\hline EB-136 & $2 . \mathrm{e}^{-135}$ & $98 \%$ & Bacillus subtilis & + & + & AB301012.1 \\
\hline EB-140 & $1 . \mathrm{e}^{-92}$ & $94 \%$ & Bacillus sp. & + & - & GQ340516.1 \\
\hline EB-141 & $1 . \mathrm{e}^{-122}$ & $96 \%$ & Lysinibacillus sp. & + & - & GU172164.1 \\
\hline EB-143 & $8 . e^{-94}$ & $96 \%$ & Bacillus sp. & + & - & JN092818.1 \\
\hline EB-144 & 0.0 & $92 \%$ & Paenibacillus sp. & + & + & EF178460.1 \\
\hline EB-145 & 0.0 & $94 \%$ & Bacillus sp. & + & - & JF896450.1 \\
\hline EB-146 & 0.0 & $96 \%$ & Bacillus sp. & + & - & HM461161.1 \\
\hline EB-147 & 0.0 & $99 \%$ & Bacillus subtilis & + & - & EU977724.1 \\
\hline EB-148 & 0.0 & $97 \%$ & Aneurinibacillus sp. & + & - & $\mathrm{AB} 112723.1$ \\
\hline EB-149 & $2 . \mathrm{e}^{-145}$ & $97 \%$ & Bacillus sp. & + & - & EU977790.1 \\
\hline EB-150 & $6 . \mathrm{e}^{-121}$ & $92 \%$ & Bacillus sp. & + & - & DQ915582.1 \\
\hline EB-151 & $2 . \mathrm{e}^{-157}$ & $95 \%$ & Bacillus sp. & + & - & AM237389.1 \\
\hline EB-152 & $1 . e^{-118}$ & $95 \%$ & Bacillus sp. & + & - & JN082257.1 \\
\hline EB-153 & $1 . \mathrm{e}^{-127}$ & $95 \%$ & Bacillus sp. & + & - & HM461228.1 \\
\hline EB-154 & $8 . \mathrm{e}^{-104}$ & $98 \%$ & Bacillus pumilus & + & - & HQ334985.1 \\
\hline EB-157 & $1 . \mathrm{e}^{-122}$ & $95 \%$ & Bacillus sp. & + & - & JN092818.1 \\
\hline EB-158 & $2 . \mathrm{e}^{-99}$ & $97 \%$ & Bacillus sp. & + & - & AJ842964.1 \\
\hline EB-161 & $1 . e^{-96}$ & $96 \%$ & Bacillus sp. & + & - & HM461161.1 \\
\hline EB-162 & $3 . \mathrm{e}^{-107}$ & $100 \%$ & Bacillus pumilus & + & - & GQ917222.1 \\
\hline EB-164 & $1 . \mathrm{e}^{-142}$ & $96 \%$ & Bacillus sp. & + & - & AY484507.1 \\
\hline EB-169 & $5 . \mathrm{e}^{-106}$ & $98 \%$ & Bacillus pumilus & + & + & FJ189791.1 \\
\hline EB-182 & 0.0 & $95 \%$ & Bacillus sp. & + & - & HG003422.1 \\
\hline EB-184 & 0.0 & $96 \%$ & Bacillus sp. & + & - & HQ218993.1 \\
\hline EB-187 & $2 . e^{-94}$ & $95 \%$ & Bacillus sp. & + & - & FM865689.1 \\
\hline EB-194 & $2 . \mathrm{e}^{-110}$ & $93 \%$ & Bacillus sp. & - & + & FJ405377.1 \\
\hline EB-196 & $5 . \mathrm{e}^{-91}$ & $95 \%$ & Enterobacter sp. & - & - & GQ260081.1 \\
\hline EB-199 & $1 . \mathrm{e}^{-92}$ & $95 \%$ & Bacillus sp. & + & - & EF522800.1 \\
\hline EB-200 & $3 . e^{-97}$ & $99 \%$ & Bacillus pumilus & + & - & EU977790.1 \\
\hline
\end{tabular}

${ }^{1}$ Probability of randomly finding the same alignment between two sequences.

${ }^{2}$ Percentage of sequence identity between the sequence of a banana isolate and a related organism.

${ }^{3}$ Organism with the partial $16 \mathrm{~S}$ rDNA sequence most homologous to that of the banana isolate.

${ }^{4}$ Accession number of the related organism sequence.

(3.9\% of isolates). Twelve Bacillus species were identified:

B. amyloliquefaciens, B. axarquiensis, B. cereus, B. flexus, $B$. megaterium, $B$. methylotrophicus, $B$. licheniformis, $B$. pumilus, B. safensis, B. subtilis, B. tequilensis and $B$. thuringiensis, indicating intraspecific variability associated with banana 'Prata Anã' roots. Bacillus pumilus and $B$. subtilis predominated among the species identified in this study and represented $20.6 \%$ and $9.8 \%$ of the isolates identified, respectively (Table 1).

\section{REP-PCR and ARDRA analysis}

The rep-PCR technique generated different molecular profiles for each primer (REP, ERIC and BOX) separately. 50 readable loci were obtained and all of the fragments were polymorphic.

Nine major clusters were identified (Figure 1). Cluster I contained 34 isolates from three genera (Paenibacillus, Bacillus and Lysinibacillus), all belonging to the phylum Firmicutes. Despite the low dissimilarity among the isolates, this group showed high genetic diversity, with repre- 


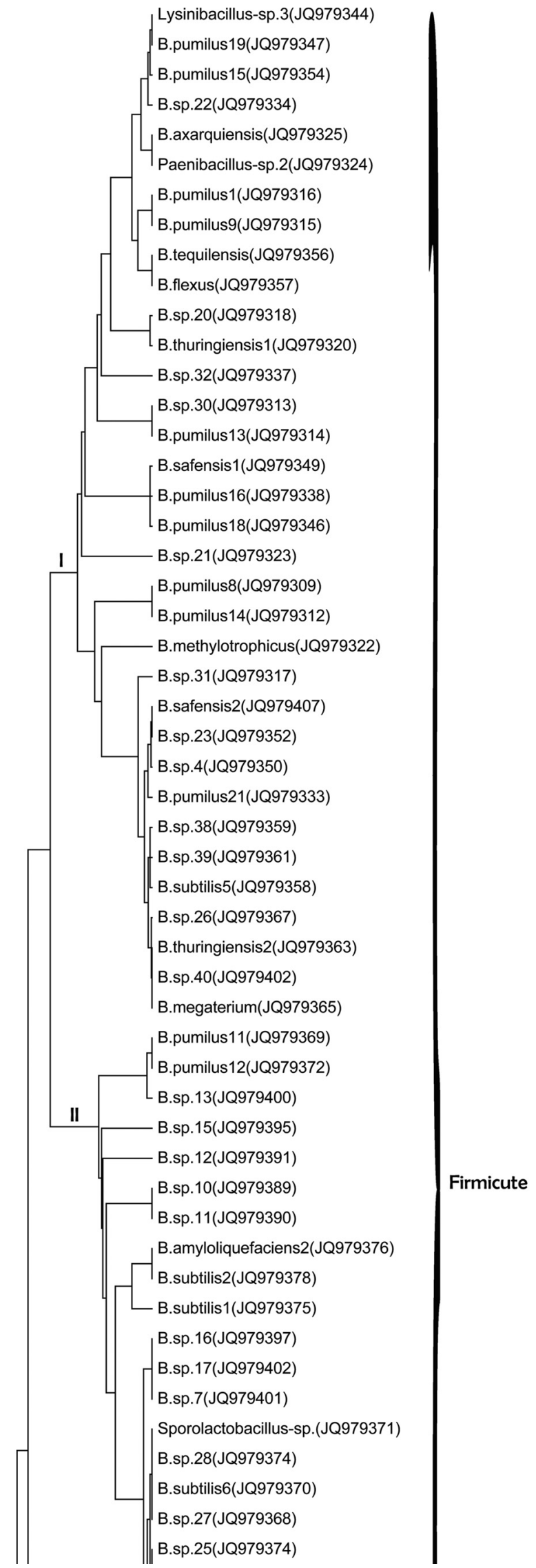

Figure 1 - Dissimilarity dendrogram based on rep-PCR amplicons of endophytic bacterial isolates from 'Prata Anã' banana roots. 


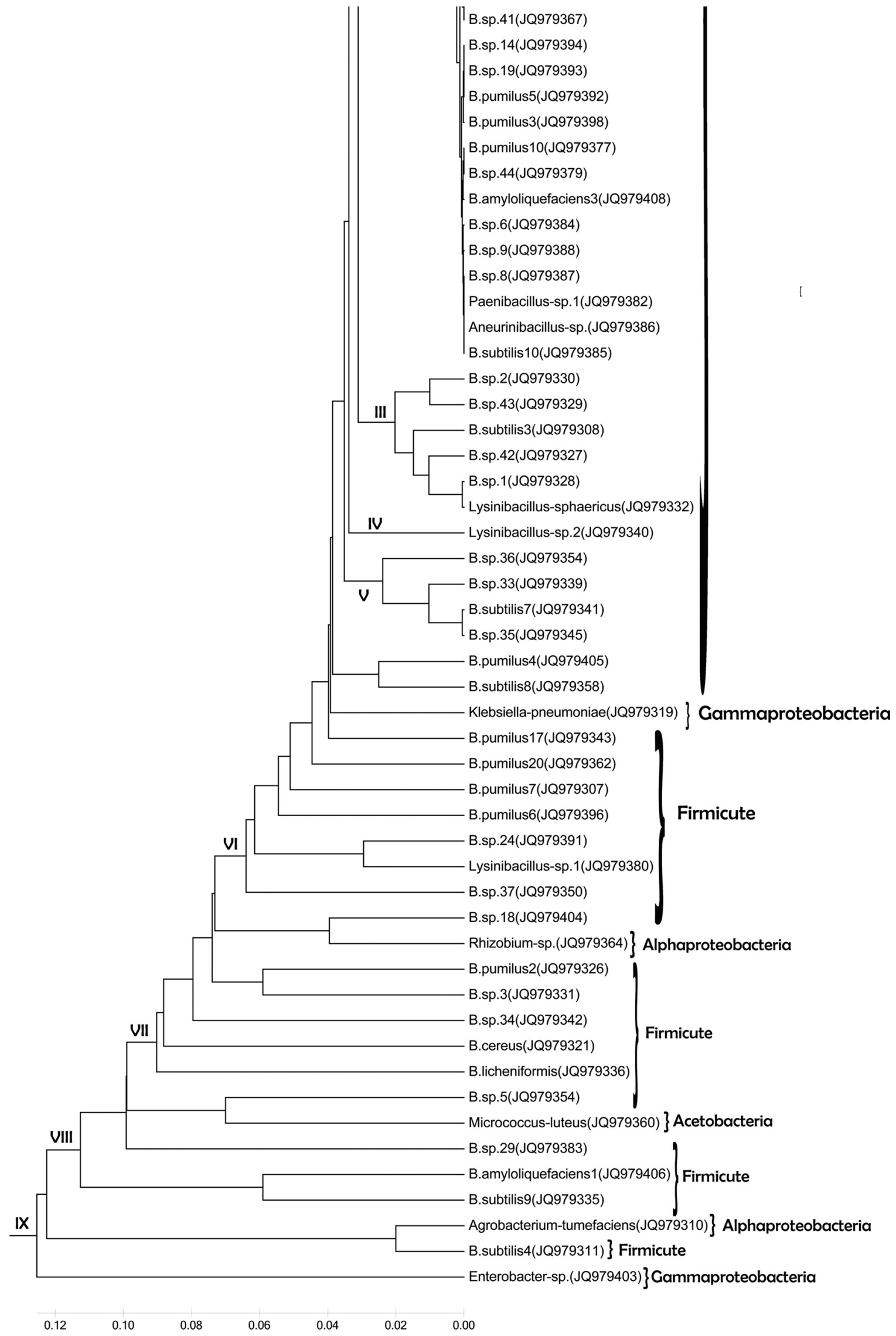

Figure 1 (cont.) - Dissimilarity dendrogram based on rep-PCR amplicons of endophytic bacterial isolates from 'Prata Anã' banana roots. 
sentatives from eight species of Bacillus. In general, the groups were formed based on phylogenetic criteria. Groups I, II, III and V were formed exclusively by bacteria of the phylum Firmicutes while group IV consisted of a single representative of the genus Lysinibacillus. Group VI contained different bacterial genera, two of which (Klebsiella and Rhizobium) belonged to the phylum Proteobacteria. $75 \%$ of the isolates in group VIII belonged to the phylum Firmicutes, the exception being Micrococcus luteus, which belonged to the phylum Actinobacteria. Group IX contained three genera (Agrobacterium tumefasciens, Enterobacter sp. and Bacillus subtilis) that belonged to three classes (Alphaproteobacteria, Gammaproteobacteria and Bacilli, respectively).

ARDRA diversity analysis of the bacterial isolates, which compared the cleavage products from four restriction enzymes, yielded 45 polymorphic and non-monomorphic bands. The restriction enzyme RsaI provided the most resolution by generating 13 bands, followed by MspI with 12 , Hinfl with 11 and NdeI with nine bands.

Phylogenetic analysis based on the ARDRA results showed that most $(96 \%)$ of the isolates were affiliated with Firmicutes, including the dominant genus Bacillus. Figure 2 shows the phylogeny of Bacillus and Lysinibacillus, with the formation of eight groups. Groups III, V, VI, VII and VIII consisted exclusively of representatives belonging to Bacillus. The four representatives of Lysinibacillus formed three groups, with groups I and II containing one isolate each while group IV contained two isolates.

The phylum Proteobacteria accounted for $3.9 \%$ of all isolates. The only member of Actinobacteria identified was Micrococcus luteus (Figure 3). Figure 3 shows six groups in which groups II, V and VI were represented by a single bacterium each. There was no common criterion by which the bacteria were grouped. Group III contained two bacteria belonging to the phylum Firmicutes (Paenibacillus sp. and Aneurinibacillus sp.).

\section{Analysis of the nifH gene}

PCR amplification of the nifH gene was detected in 24 of the 102 bacterial isolates; $79 \%$ of the isolates belonged to the genus Bacillus. Seven species of Bacillus were nifH-positive, including: B. amyloliquefaciens, B. cereus, B. flexus, B. licheniformis, B. pumilus, B. subtilis and $B$. tequilenses. The other isolates belonged to the genera Klebsiella, Lysinibacillus, Paenibacillus and Sporolactobacillus (Table 1).

\section{DISCUSSION}

Studies of plants and endophytic bacteria have demonstrated the importance of such interactions for plant adaptation to diverse ecosystems and for enhancing soil health and quality. However, little is known about the colonizing species, the relationship between these bacteria and banana trees, and the possible benefits of this interaction.

Of the 201 bacterial isolates collected in this study, $75 \%$ were classified as Gram-positive. In contrast, Thomas et al. (2008), in a study of endophytic bacteria isolated from banana shoot tip cultures during the first passage in vitro encountered more Gram-negative organisms (75\%). Together, these findings agree with other reports regarding the marked diversity of Gram-negative and Gram-positive endophytic bacteria in banana (Habiba et al., 2002; Ganen et al., 2009).

The lack of a hypersensitivity reaction for the 201 bacterial isolates suggested the absence of phytopathogenic bacteria. The species $A$. tumefaciens was identified here but did not elicit a hypersensitivity response in non-host plants, although it behaved as an endophytic bacterium in banana trees. According to Kobayashi and Palumbo (2000), some

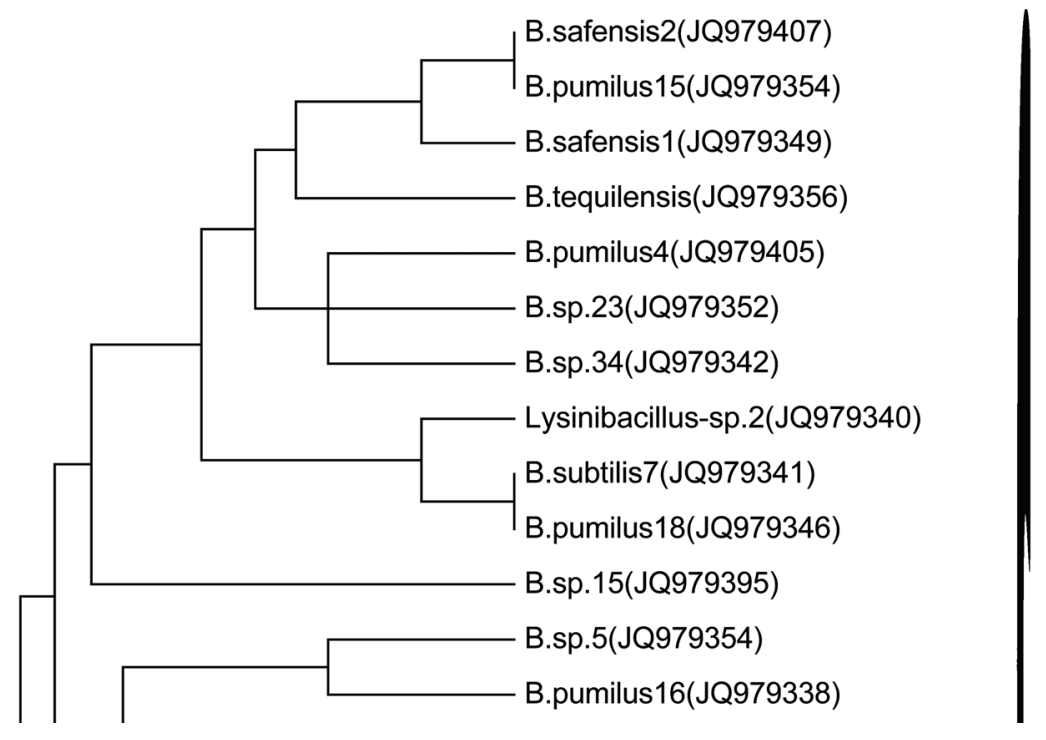

Figure 2 - Dendrogram based on genetic dissimilarity matrix values of Bacillus and Lysinibacillus isolates analyzed by PCR-ARDRA. 


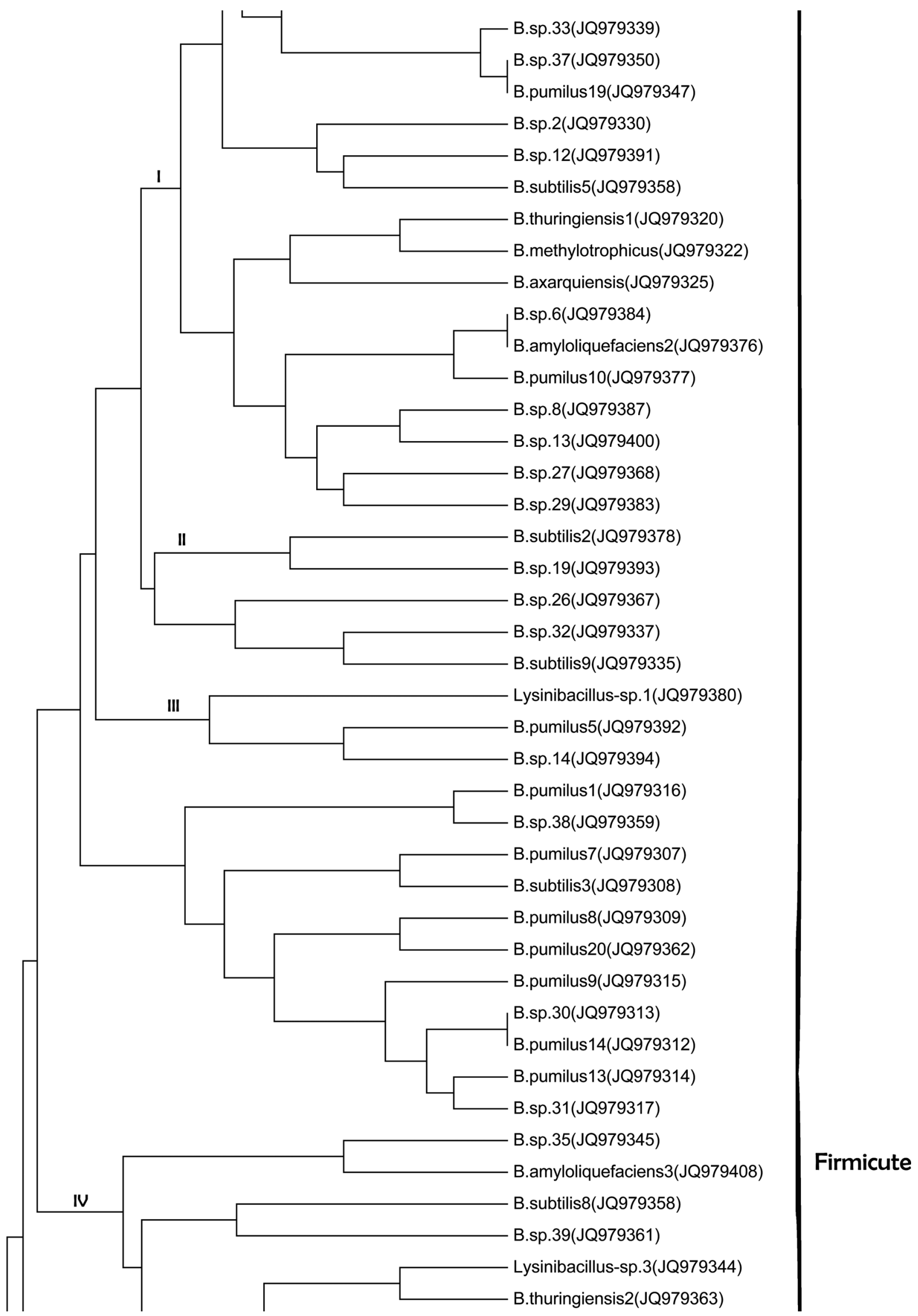

Figure 2 (cont.) - Dendrogram based on genetic dissimilarity matrix values of Bacillus and Lysinibacillus isolates analyzed by PCR-ARDRA. 


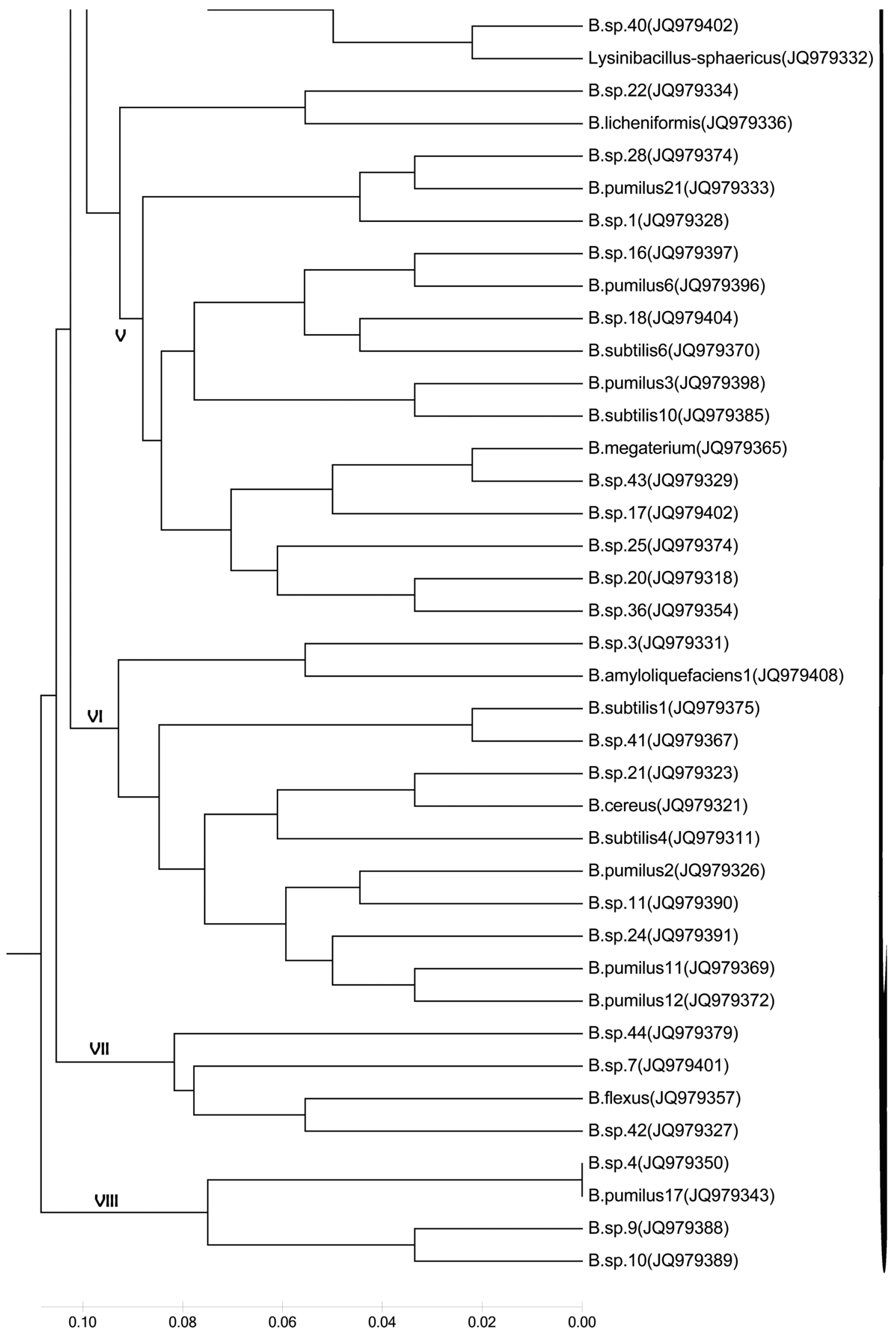

Figure 2 (cont.) - Dendrogram based on genetic dissimilarity matrix values of Bacillus and Lysinibacillus isolates analyzed by PCR-ARDRA. 


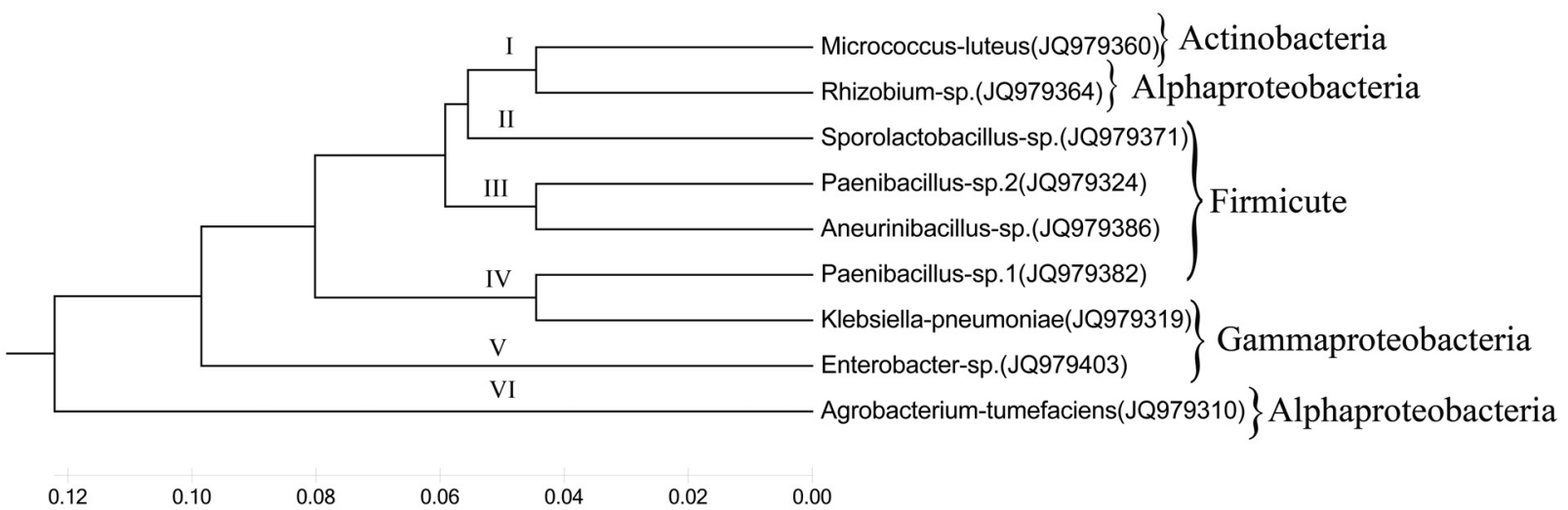

Figure 3 - PCR-ARDRA dendrogram of genetic dissimilarity showing the phylogenetic relationships among nine isolates from banana 'Prata Anã' roots.

phytobacteria genera are typical endophytic bacteria without causing any symptoms of illness in the associated plant. The host and pathogen developmental stage, environmental changes and host defense responses (Schulz and Boyle, 2005), as well as genetic, structural and physiological factors can determine whether a microorganism is endophytic or phytopathogenic (Andreote et al., 2008).

Sequence analyses using BLASTn revealed high bacterial diversity in the roots of 'Prata Anã' banana plants. Many bacterial genera, such as Bacillus and other species identified here have also been identified in other studies of endophytic bacteria. The genera Bacillus, Enterobacter and Pantoea have been identified as endophytes in several plants, such as citrus, sugar cane and soybean (Medrano and Bell, 2007; Magnani et al., 2010).

Bacillus was the most frequently encountered genus in this study. The Bacillus species identified here (B. cereus, $B$. subtilis, B. megaterium and B. pumilus) have been described as endophytic species (Elvira-Recuenco and Van Vuurde, 2000; Araújo et al., 2002) and have also been isolated from contaminated banana explants in tissue culture (Odutayo et al., 2007; Jie et al., 2009). Bacillus bacteria are classified as growth promoters (characterized by the production of auxins and gibberellins by B. pumilus), nitrogen fixers and phosphate solubilizers (Forchetti et al., 2007).

Lysinibacillus was the second most frequently identified genus. Species belonging to this genus have been associated with ginseng plants and the isolates evaluated were positive for most of the plant growth promoters (Vendan et al., 2010). Despite the predominance of Bacillus isolates, species of Paenibacillus were also identified and are of considerable biotechnological potential. Paenibacillus species not only have the capacity to produce plant growth hormones (auxins and cytokinins), enzymes (chitinases, amylases and proteases) and antibiotics but also can solubilize organic phosphates (Coelho et al., 2009).

Only one representative each of Enterobacter and Rhizobium was found to be associated with banana roots. Enterobacter species are endophytes in Citrus spp., soybean and banana (Araujo et al., 2002; Kuklinsky-Sobral et al., 2004; Thomas et al., 2008; Jie et al., 2009). Enterobacter species can fix nitrogen and solubilize phosphate (Asis Jr and Adachi, 2003; Dalton et al., 2004), thereby increasing plant growth and productivity.

Rhizobium species have been widely used as biofertilizers for various legume species. In banana, a few reports have described Rhizobium spp. associated with Musa spp. A study by Martinez et al. (2003) reported significant increases in stem and leave fresh weight in bananas after the inoculation of some Rhizobium isolates.

Although A. tumefaciens is described as phytopathogenic this species has been reported as an endophytic bacterium that is asymptomatically associated with the roots of Triticum aestivum L. (Sharma et al., 2005), the stems of Rosa grandiflora (Martí et al., 1999) and the roots and stems of Crotalaria pudica, Crotalaria pallida and Mimosa pudica (Wang et al., 2008). Wang et al. (2008) also observed that $A$. tumefaciens was able to thrive in nodules formed by Sinorhizobium meliloti in Melilotus dentatus. According to Llop et al. (2009), the asymptomatic association of A. tumefaciens with host plants may reflect a loss of pathogenicity. To our knowledge, this is the first report on identify A. tumefaciens living as an endophyte in Musa spp. This association suggests that these isolates may be present in the soil and enter the plant through secondary roots.

The BOX primer yielded the greatest number of polymorphic bands and had the best resolving power among the bacterial isolates. According to Van Berkum (1999), BOX regions are associated with a high degree of polymorphisms and consequently participate in adaptive evolution by mediating the interactions of microorganisms with harsh or adverse environments.

The ARDRA technique was efficient in identifying variation among bacterial isolates evaluated by polymorphisms and estimates of genetic distance. The variations observed among bacteria are based on the generation of different band profiles that reveal the diversity among and within bacterial groups and group individuals of similar genotypes (Kuklinsky-Sobral et al., 2004). Assumpção et al. (2009) stated that the diversity and structure of microbial 
communities varies with the sample size because the probability of finding rare species increases with increasing sample size.

The detection of the nifH gene indicated that $23.5 \%$ of the endophytic bacteria analyzed could act as nitrogen fixers. Most of these nitrogen fixers belonged to the genus $\mathrm{Ba}$ cillus, which has already been described as potential nitrogen fixers (Raymond et al., 2004). The nifH gene was also present in the genus Rhizobium and $K$. pneumoniae. The presence of this gene is strong evidence of the nitrogen-fixing ability in bacteria because this gene encodes the Fe-nitrogenase subunit of the nitrogenase complex. The nifH gene has therefore become a useful marker for studying the diversity of endophytic bacteria with the potential to fix $\mathrm{N}_{2}$ in independent culture studies (Izquierdo and Nüsslein, 2006).

The distribution of phylogenetic groups showed a predominance of members of Firmicutes (96\%). In contrast, Jie et al. (2009), in a study of the re-introduction of naturally-occurring endophytes into tissue culture banana plantlets, noted a high proportion of members of the phylum Proteobacteria (87.7\%). Both studies demonstrated the potential effect of cultivars, climatic conditions and soil on the genetic diversity of endophytic bacteria in bananas.

The isolation, identification and screening of endophytic bacteria as plant growth regulators, as well as their ability to increase plant nutrient absorption and stimulate the development of resistance towards abiotic and biotic stress, are essential leads for establishing their applications in agriculture, especially the cultivation of bananas (Cao et al., 2004; Jaizme-Vega et al., 2004; Jie et al., 2009).

The marked genetic diversity observed here and in other studies of endophytic bacteria in banana represents an emerging trend in biotechnology. However, further studies on the molecular and biochemical mechanisms of growth promotion and on the usefulness of artificial inoculation must be done in order to meet the expectations of largescale banana producers.

\section{Acknowledgments}

The authors thank FAPEMIG, CNPq and CAPES for financial support and fellowships.

\section{References}

Altschul SF, Madden TL, Schaffer AA, Zhang J, Zhang Z, Miller W and Lipman DJ (1997) Gapped BLAST and PSI-BLAST: A new generation of protein database search programs. Nucleic Acids Res 25:3389-3402.

Andreote FD, Mendes R, Dini-Andreote F, Rossetto PB, Labate CA, Pizzirani-Kleiner AA, Van Elsas JD, Azevedo JL and Araujo WL (2008) Transgenic tobacco revealing altered bacterial diversity in rizosphere during early plant development. Antonie van Leeuwenhoek 93:415-424.

Araujo WL, Marcon J, Maccheroni Jr W, Van Elsas JD, Van Vuurde JWL and Azevedo JL (2002) Diversity of endo- phytic bacterial populations and their interactions with Xylella fastidiosa in Citrus plants. Appl Environ Microbiol 68:4906-4914.

Asis Jr CA and Adachi K (2003) Isolation of endophytic Pantoea agglomerans and nondiazotrophic Enterobacter asburiae from sweetpotato stem in Japan. Lett Appl Microbiol 38:19-23.

Assumpção LC, Lacava PT, Dias ACF, Azevedo JL and Menten JOM (2009) Diversidade e potencial biotecnológico da comunidade bacteriana endofítica de sementes de soja. Pesq Agrop Bras 44:503-510.

Aung TN, Nourmohammadi S, Sunitha EM and Myint M (2011) Isolation of endophytic bacteria from green gram and study on their plant growth promoting activities. Intl J Appl Biol Pharmacol Tech 2:525-536.

Cao L, Qiu Z, Dai Q, Tan H, Lin Y and Zhou S (2004) Isolation of endophytic actinomycetes from roots and leaves of banana (Musa acuminata) plants and their activities against Fusarium oxysporum f. sp. cubense. World J Microbiol Biotechnol 20:501-504.

Dalton DA, Kramer S, Azios N, Fusaro S, Cahill E and Kennedy C (2004) Endophytic nitrogen fixation in dune grasses (Ammophila arenaria and Elymus mollis) from Oregon. FEMS Microbiol Ecol 49:469-479.

Elvira-Recuenco M and Van Vuurde JWL (2000) Natural incidence of endophytic bacteria in pea cultivars under field conditions. Can J Microbiol 46:1036-1041.

Forchetti G, Masciarelli O, Alemano S, Alvarez D and Abdala G (2007) Endophytic bacteria in sunflower (Helianthus annuus L.): Isolation, characterization, and production of jasmonates and abscisic acid in culture medium. Appl Microbiol Biotechnol 76:1145-1152.

Ganen STS, Nietsche S, Pereira MCT, Reis ST, Xavier AA, Santos TM and Fernandes TP (2009) Microbial contamination in explants of banana cultivars 'Galil 18' and 'Tropical'. Acta Hort 829:341-344.

Germaine KJ, Liu X, Cabellos GG, Hogan JP, Ryan D and Dowling DN (2009) Bacterial endophyte-mediated naphthalene phytoprotection and phytoremediation. FEMS Microbiol Lett 296:226-234

Habiba U, Reza S, Saha ML, Khan MR and Hadiuzzaman S (2002) Endogenous bacterial contamination during in vitro culture of banana: Identification and prevention. Plant Tissue Cult 12:117-124.

Izquierdo JA and Nüsslein K (2006) Distribution of extensive nifH gene diversity across physical soil microenvironments. Microbiol Ecol 51:441-452.

Jaizme-Vega MC, Rodríguez-Romero AS and Guerra MSP (2004) Potential use of rhizobacteria from the Bacillus genus to stimulate the plant growth micropropagated bananas. Fruits 59:83-90.

Jie L, Zifeng W, Lixiang C, Hongming T, Patrik I, Zide J and Shining Z (2009) Artificial inoculation of banana tissue culture plantlets with indigenous endophytes originally derived from native banana plants. BioControl 51:427-434.

Kobayashi DY and Palumbo JD (2000) Bacterial endophytes and their effects on plants and uses in agriculture. In: Bacon CW and White Jr JF (eds) Microbial Endophytes. Marcel Dekker, New York, pp 199-233.

Kuklinsky-Sobral J, Araujo WL, Mendes R, Geraldi IO, Pizzirani-Kleiner AA and Azevedo JL (2004) Isolation and char- 
acterization of soybean associated bacteria and their potential for plant growth promotion. Environ Microbiol 6:1244-1251.

Llop P, Murillo J, Lastra B and Lopezi MM (2009) Recovery of nonpathogenic mutant bacteria from tumors caused by several Agrobacterium tumefaciens strains: A frequent event? Appl Environ Microbiol 75:6504-6514.

Louws FJ, Fulbright DW and Stephens CT (1994) Specific genomic fingerprints of phytopathogenic Xanthomonas and Pseudomonas pathovars and strains generated with repetitive sequences and PCR. Appl Environ Microbiol 60:22862295.

Magnani GS, Didonet CM, Cruz LM, Picheth CF, Pedrosa FO and Souza EM (2010) Diversity of endophytic bacteria in Brazilian sugarcane. Genet Mol Res 9:250-258.

Martí R, Cubero J, Daza A, Piquer J, Salcedo CI, Morente C and López MM (1999) Evidence of migration and endophytic presence of Agrobacterium tumefaciens in rose plants. Eur J Plant Pathol 105:39-50.

Martinez L, Caballero-Mellado J, Orozco J and Martinez-Romero E (2003) Diazotrophic bacteria associated with banana (Musa spp.). Plant Soil 257:35-47.

Medrano EG and Bell AA (2007) Role of Pantoea agglomerans in opportunistic bacterial seed and boll rot of cotton (Gossypium hirsutum) grown in the field. J Appl Microbiol 102:134-143.

Mia MAB, Shamsuddin ZH and Mahmood M (2010) Use of plant growth promoting bacteria in banana: A new insight for sustainable banana production. Int J Agr Biol 12:459-467.

Odutayo OI, Amusa NA, Akutade OO and Ogunsanwo YR (2007) Sources of microbial contamination in tissue culture laboratories in southwestern Nigeria. Afr J Agric Res 2:67-72.

Raymond J, Siefert JL, Staples CR and Blankenship RE (2004) The natural history of nitrogen fixation. Mol Biol Evol 21:541-554.

Rosenblueth M, Martinez L, Silva J and Martinez-Romero E (2004) Klebsiella variicola, a novel species with clinical and plant-associated isolates. Syst Appl Microbiol 19:827-837.

Romeiro RS (2001) Métodos em Bacteriologia de Plantas. UFV, Viçosa, 279 pp.

Ryan RP, Germaine K, Franks A, Ryan DJ and Dowling DN (2008) Bacterial endophytes: Recent developments and applications. FEMS Microbiol Lett 278:1-9.
Schulz B and Boyle C (2005) The endophytic continuum. Mycol Res 109:661-686.

Sharma PK, Sarita S and Prell J (2005) Isolation and characterization of an endophytic bacterium related to Rhizobium/Agrobacterium from wheat (Triticum aestivum L.) roots. Curr Sci 89:608-610.

Tamura K, Peterson D, Peterson N, Stecher G, Nei M and Kumar S (2011) MEGA5: Molecular Evolutionary Genetics Analysis using maximum likelihood, evolutionary distance, and maximum parsimony methods. Mol Biol Evol 10:27312739.

Thomas P, Swarna GK, Roy PK and Patil P (2008) Identification of culturable and originally non-culturable endophytic bacteria isolated from shoot tip cultures of banana cv. Grand Naine. Plant Cell Tissue Organ Cult 93:55-63.

Ting ASY, Meon S, Kadir J, Radu S and Singh G (2008) Endophytic microorganisms as potential growth promoters of banana. BioControl 53:541-553.

Van Berkum A (1999) Short sequence repeats in microbial pathogenesis and evolution. Cell Mol Life Sci 56:729-734.

Vendan R, Yu Y, Lee S and Rhee YH (2010) Diversity of endophytic bacteria in ginseng and their potential for plant growth promotion. J Microbiol 48:559-565.

Wang LL, Wangi ET, Liu J, Li Y and Chen WX (2008) Endophytic occupation of root nodules and roots of Melilotus dentatus by Agrobacterium tumefaciens. Microbiol Ecol $52: 436-443$.

\section{Internet resources}

Coelho MRR, Carneiro NP, Marriel IE and Seldin L (2009) Método molecular para estudos ecológicos de bactérias diazotróficas do gênero Paenibacillus em amostras ambientais. http://www.cnpms.embrapa.br/publicacoes/publica/2009/b oletim/Bol_10.pdf (January 2, 2010).

FAO (2010) Food and Agricultural Organization http://www.faostat.fao.org/site/567/default.aspx/1. (March $3,2010)$.

Associate Editor: Guilherme Correa de Oliveira

License information: This is an open-access article distributed under the terms of the Creative Commons Attribution License, which permits unrestricted use, distribution, and reproduction in any medium, provided the original work is properly cited. 